\title{
Nurses Knowledge Regarding Sickle Cell Disease among Children- National Ribat University Hospital 2018
}

\section{Elkheir RHM and Mokhtar KM*}

National Ribat University Hospital, Sudan

*Corresponding author: Kawther Mohammed Mokhtar, National Ribat University, Sudan, Tel: 0912233346; Email: Kawther_mokhtar@hotmail.com

\section{Research Article}

Volume 3 Issue 5

Received Date: August 01, 2019

Published Date: September 18, 2019

DOI: $10.23880 /$ nhij- 16000202

\section{Abstract}

Background: Sickle cell disease (SCD) is consider one of the inheritance blood diseases resulting from abnormal mutation in the form of crescent red blood cells (1) Nurses have vital role for caring of pediatric patient with sickle cell disease. Descriptive cross sectional study was conducted in national ribat university hospital, the study aimed to assess nurse's knowledge regarding sickle cell disease.

Method: Data collected by self-administer questionnaire which include two-part personal data and information about sickle cell disease. The analysis of the data by statistical package SPSS using percentage and correlation coefficient.

Results: The results show that most of the nurses $94 \%$ knowledgeable about management of crises and complication but there are not know about health education for the patient what is very importance Also the results show that there was a significant relationship between nurses. Knowledge, level of education and their experience (P value 0.000). The study recommends periodic work shop for nurses regarding common diseases.

Keywords: Nursing; Blood cells; Disease; Hemoglobin

Abbreviations: ATP: Adenosine Triphosphate; DNA: Deoxy Ribonucleic Acid; GFR: Glomerular Filtration Rate; Hb: Hemoglobin; HbA: Adult Hemoglobin; HbF: Fetal Hemoglobin; HbSS: Sickle Cell Hemoglobin; IgS: Immunoglobulin G; MRI: Magnetic Resonance Imagine; SCA: Sickle Cell Anemia; SCD: Sickle Cell Disease; TWBC: Total White Blood Cell Count.

\section{Introduction}

Sickle cell anemia is a group of autosomal recessive genetic blood disorders characterized by a single point mutation in sixth codon of the beta globin's gene. Under low oxygen tension, resultant abnormal hemoglobin polymerizes and causes rigged and sickle shaped red blood cells [1]. Homozygous sickle disease ((HBSS)), also known as sickle cell anemia is the major and severest from the disease [2]. A Vasco-occlusive crisis is the main clinical manifestation is accompanied by hemolysis and is main causes of hospitalization and requiring blood transfusion to avoid organ damage and death. More than $10 \%$ of patients with sickle cell anemia develop overt stroke, and $22 \%$ show evidence of silent cerebral infraction [3].

Sickle cell disease is believed to be the most frequent inherited blood disorder in the global affecting an estimated hundred million people world wild and in particular, the black races and persons of Mediterranean [3]. In Africa, sickle cell disease is the most trivalent 


\section{Nursing \& Healthcare International Journal}

genetic disease with high mortality rate at age 1-5 years $[4,5]$. In the United States of America, sickle cell disease has found to be most frequent autosomal receives gene disorder affecting approximating 1:375 of African ancestry [6]. In sub-Saharan Africa, the prevalence of the sickle cell trait ranges between $5 \%$ and $40 \%$ of the population, and $>230000(0,74 \%$ of total birth $)$ infants are born with sickle cell anemia every year. In Africa, the life expectancy of patients with sickle cell disease is less than 5 years of age are at the highest risk of death [4].

Sudan includes variable ethnic groups that range from Arabs to Africans and afro-Arabs tribes. These ethnic groups include groups with Negroid genetic characteristic with an established history in the area such as Nuba and Nilotes. Other groups include Arabs, Hausa and Copt who migrated to the area in different times in history, as well as the Arab. Negroid admixture tribes $[1,2]$.

First cousin marriage rate in Sudan are amongst the highest worldwide reaching $40-54 \%$ of all marriages $[4,6]$. The sickle cell disease was early detected in Sudan [7], the first reported case of sickle cell anemia in Sudan was in 1926 by Archibald [3] and it was the first reported case in Africa. The highest prevalence of SCD in Sudanese among population from the western Sudan [8]. SCD is the one of the types of anemia specially in western Sudan where the gene I frequent $[9,10]$.

It is believed that the sickle cell disease gene may have been preferentially introduces through males of migrating West African tribes to Sudan particularly Hausa, Fulani and Vargo [11].

\section{General Objective}

To assess Nurses Knowledge regarding sickle cell disease in pediatric department.

\section{Specific Objectives}

- To evaluate Nurses knowledge regarding sickle cell disease.

- To correlate between Nurses knowledge regarding sickle cell disease their Level of education and their experiences.

\section{Materials and Methods}

\section{Study Design}

This is descriptive cross sectional hospital based study design was conducted to assess nurse's knowledge regarding Sickle cell disease in pediatric department Ribat university hospital from in 2017.

\section{Study Area}

The descriptive study was carried out in National Ribat university hospital located in Khartoum state. The hospital contains many departments, the pediatric department is one of a largest word in hospital, and it including three department pediatric medicines is a big words it including four units. Eight rooms general words private four private 8 beds. Nurses are 36 nurses. Second department pediatric surgery, including four rooms general word each room including 8 beds (32 beds), and three private room, the third department is pediatric emergency room, it including two rooms. 5 beds, 10 nurse working there.

\section{Study Period}

Study was conducted in the period from (April 2017 to January 2018).

\section{Study Population}

Qualified nurses who working in pediatric department in Ribat university hospital.

\section{Sample Size and Sampling Technique}

70 nurses. Who are working there?

\section{Data Collection Tools and Technique}

For assessment of nurses knowledge administered questionnaire was used which covered all objective. The questionnaire including two section which are: demographic data. Section two the information regarding sickle cell disease.

\section{Study Variable}

-Age, Sex, Year of experience and Qualification.

Knowledge regarding sickle cell disease: Definition Sickle cell disease, Geographical and common area for sickle cell disease in Sudan, life expectancy for People living with sickle cell disease, the common clinical features are manifested by sickle cell disease, antenatal and neonatal screening, the diagnoses tests for sickle cell disease, the general management of sickle cell disease and management of pain episode, complication of sickle cell disease, environmental factors and socioeconomic status and Health education and counseling play. 


\section{Statistic Data Analysis}

Data was checked, coded and was exported to SPSS version 18 for analysis. The score of knowledge domains calculated as the number of correct response divided by total number of each domain question then this ratio expressed in percentage.

Pearson chi square was used to identify the association between the nurse's knowledge and demographic data. The data presentation was shown in tables.

\section{Ethical Consideration}

Ethical clearance was obtained from the faculty of graduate studies research committee. The National Ribat University through faculty of nursing science facilitated and official letter written to selected hospital to get permission.

Verbal consent was obtained from each participant, the researchers respecting the rights of participants draw or treated data with confidentiality.

\section{Reliability of the Scale}

\section{- Cronbach's Alpha method}

Where reliability was calculated using Cronbach's alpha equation shown below:

Reliability coefficient $=\frac{n}{N-1} * \frac{1-\text { Total variation questions }}{\text { variation college grades }}$

Validity $=\sqrt{\frac{n}{N-1} * \frac{1-\text { Total variations questions }}{\text { Variation college grades }}}$

Alpha coefficient $=(0.80)$, a reliability coefficient is high and it indicates Cronbach's the stability of the scale and the validity of the study.

Validity coefficient is the square of the island so reliability coefficient is (0.89), and this shows that there is a high sincerity of the scale and that the benefit of the study.

\section{Result}

\begin{tabular}{|c|c|c|}
\hline Value & Frequencies & Percentage \\
\hline $20-30$ years & 43 & $61.40 \%$ \\
\hline 31-40 years & 26 & $37.10 \%$ \\
\hline Above 41 years & 1 & $1.40 \%$ \\
\hline Total & 70 & $100.00 \%$ \\
\hline
\end{tabular}

Table 1: Illustrates the age of nurses.
(Table 1) the illustrate views most of nurses age between 20-30 years.

\begin{tabular}{|c|c|c|}
\hline Value & Frequencies & Percentage \\
\hline Male & 1 & $1.40 \%$ \\
\hline Female & 69 & $98.60 \%$ \\
\hline Total & 70 & $100.00 \%$ \\
\hline
\end{tabular}

Table 2: Illustrates the gender of nurses.

(Table 2) the illustrate views the majority of nurses female.

\begin{tabular}{|c|c|c|}
\hline Value & Frequencies & Percentage \\
\hline Diploma & 5 & $7.10 \%$ \\
\hline Bachelor & 59 & $84.30 \%$ \\
\hline Post graduate & 6 & $8.60 \%$ \\
\hline Total & 70 & $100.00 \%$ \\
\hline
\end{tabular}

Table 3: Illustrates nurse's level of education.

(Table 3) the illustrate views a major of nurses holding bachelor certificates.

\begin{tabular}{|c|c|c|}
\hline Value & Frequencies & Percentage \\
\hline 0-5 years & 39 & $55.70 \%$ \\
\hline 6-10 years & 24 & $34.30 \%$ \\
\hline Above 11 years & 7 & $10.00 \%$ \\
\hline Total & 70 & $100.00 \%$ \\
\hline
\end{tabular}

Table 4: Illustrates the Years of experience.

(Table 4) the illustrate views most of nurses working under five years.

\begin{tabular}{|c|c|c|}
\hline Value & Frequencies & Percentage \\
\hline Yes & 66 & $94.30 \%$ \\
\hline No & 3 & $4.30 \%$ \\
\hline I do not know & 1 & $1.40 \%$ \\
\hline Total & 70 & $100.00 \%$ \\
\hline
\end{tabular}

Table 5: Illustrates the definition of SCD.

(Table 5) the illustrate views most of nurses knowable about the definition of SCD.

\begin{tabular}{|c|c|c|}
\hline Value & Frequencies & Percentage \\
\hline Yes & 63 & $90.00 \%$ \\
\hline No & 2 & $2.90 \%$ \\
\hline I do not know & 5 & $7.10 \%$ \\
\hline Total & 70 & $100.00 \%$ \\
\hline
\end{tabular}

Table 6: Illustrates nurse's knowledge regarding the ethnic group of people affected by sickle cell disease in Africa. 
(Table 6) the illustrate views the most of nurses know about the most common people affected by SCD in world lives in Africa.

\begin{tabular}{|c|c|c|}
\hline Value & Frequencies & Percentage \\
\hline Yes & 61 & $87.10 \%$ \\
\hline No & 3 & $4.30 \%$ \\
\hline I don't know & 6 & $8.60 \%$ \\
\hline Total & 70 & $100.00 \%$ \\
\hline
\end{tabular}

Table 7: Illustrates knowledge of nurses regarding geographic area for sickle cell disease in Sudan (sickle cell disease is common in western state).

(Table 7) illustrate that the most of nurses know about the common area affected by SCD in Sudan the western Sudan.

\begin{tabular}{|c|c|c|}
\hline Value & Frequencies & Percentage \\
\hline Yes & 61 & $87.10 \%$ \\
\hline No & 5 & $7.10 \%$ \\
\hline I don't know & 4 & $5.70 \%$ \\
\hline Total & 70 & $100.00 \%$ \\
\hline
\end{tabular}

Table 8: Illustrates knowledge of nurses regarding the common clinical features are manifested by sickle cell disease and pain crises.

(Table 8) illustrate views the most of nurses know about common clinical features of SCD are manifestation.

\begin{tabular}{|c|c|c|}
\hline Value & Frequencies & Percentage \\
\hline Yes & 52 & $74.30 \%$ \\
\hline No & 9 & $12.90 \%$ \\
\hline I don't know & 9 & $12.90 \%$ \\
\hline Total & 70 & $100.00 \%$ \\
\hline
\end{tabular}

Table 9: Illustrates knowledge of nurses regarding Antenatal screening is appropriate test for sickle cell disease.

(Table 9) illustrate that the most of nurses know about the appropriate test of SCD.

\begin{tabular}{|c|c|c|}
\hline Value & Frequencies & Percentage \\
\hline Yes & 62 & $88.60 \%$ \\
\hline No & 6 & $8.60 \%$ \\
\hline I don't know & 2 & $2.90 \%$ \\
\hline Total & 70 & $100.00 \%$ \\
\hline
\end{tabular}

Table 10: Illustrate nurses' knowledge regarding diagnostic sickle cell disease test (complete blood count \& skilling test are appropriate tests).
(Table 10) illustrate that most of nurses know about the appropriate testing to diagnostic SCD.

\begin{tabular}{|c|c|c|}
\hline Value & Frequencies & Percentage \\
\hline Yes & 62 & $88.60 \%$ \\
\hline No & 3 & $4.30 \%$ \\
\hline I don't know & 5 & $7.10 \%$ \\
\hline Total & 70 & $100.00 \%$ \\
\hline
\end{tabular}

Table 11: The illustrate nurses knowledge regarding shape of RBC in sicklier patient's blood.

(Table 11) illustrate that most of nurses know the shape of RBCs of SCD.

\begin{tabular}{|c|c|c|}
\hline Value & Frequencies & Percentage \\
\hline Yes & 67 & $95.70 \%$ \\
\hline No & 1 & $1.40 \%$ \\
\hline I don't know & 2 & $2.90 \%$ \\
\hline Total & 70 & $100.00 \%$ \\
\hline
\end{tabular}

Table 12: Illustrates of the general management of sickle cell disease are maintain adequate fluid intake, treat infection promptly and vitamins supplementary.

(Table 12) illustrate that most of the nurses know general management of SCD.

\begin{tabular}{|c|c|c|}
\hline Value & Frequencies & Percentage \\
\hline Yes & 57 & $81.40 \%$ \\
\hline No & 6 & $8.60 \%$ \\
\hline I don't know & 7 & $10.00 \%$ \\
\hline Total & 70 & $100.00 \%$ \\
\hline
\end{tabular}

Table 13: Illustrates nurses' knowledge regarding the management of pain episodes by narcotic analgesics.

(Table 13) illustrate views the most of nurses know about the pain management of SCD.

\begin{tabular}{|c|c|c|}
\hline Value & Frequencies & Percentage \\
\hline Yes & 63 & $90.00 \%$ \\
\hline No & 2 & $2.90 \%$ \\
\hline I don't know & 5 & $7.10 \%$ \\
\hline Total & 70 & $100.00 \%$ \\
\hline
\end{tabular}

Table 14: Illustrates the knowledge of the nurses regarding appropriate management of sever painful crises are given morphine parentally, rehydration and blood transfusions.

(Table 14) Illustrate that most of the nurses know about the appropriate management of sever painful crises. 


\section{Nursing \& Healthcare International Journal}

\begin{tabular}{|c|c|c|}
\hline Value & Frequencies & Percentage \\
\hline Yes & 56 & $80.00 \%$ \\
\hline No & 5 & $7.10 \%$ \\
\hline I don't know & 9 & $12.90 \%$ \\
\hline Total & 70 & $100.00 \%$ \\
\hline
\end{tabular}

Table 15: Illustrates the knowledge of the nurses about effective management of the stroke in sickle cell disease.

(Table 15) illustrate that most of nurses know about the effective management of stroke.

\begin{tabular}{|c|c|c|}
\hline Value & Frequencies & Percentage \\
\hline Yes & 52 & $74.30 \%$ \\
\hline No & 8 & $11.40 \%$ \\
\hline I don't know & 10 & $14.30 \%$ \\
\hline Total & 70 & $100.00 \%$ \\
\hline
\end{tabular}

Table 16: Illustrates the knowledge of the nurses about iron accumulated in vital organs is a complications of recurrent of blood transfusion.

(Table 16) illustrate that the most of nurses know about the complication of recurrent of blood transfusion.

\begin{tabular}{|c|c|c|}
\hline Value & Frequencies & Percentage \\
\hline Yes & 57 & $81.40 \%$ \\
\hline No & 7 & $10.00 \%$ \\
\hline I don't know & 6 & $8.60 \%$ \\
\hline Total & 70 & $100.00 \%$ \\
\hline
\end{tabular}

Table 17: Illustrates the knowledge about complications of sickle cell disease can be pain crises, stroke and lung tissue damage.

(Table 17) illustrate that the most of nurses know about the complication of SCD.

\begin{tabular}{|c|c|c|}
\hline Value & Frequencies & Percentage \\
\hline Yes & 60 & $85.70 \%$ \\
\hline No & 2 & $2.90 \%$ \\
\hline I don't know & 8 & $11.40 \%$ \\
\hline Total & 70 & $100.00 \%$ \\
\hline
\end{tabular}

Table 18: Illustrates the knowledge nurses about complication of sickle

(Table 18) illustrate that the most of nurses know about splenomegaly is one of complication of SCD can be treated surgical.

\begin{tabular}{|c|c|c|}
\hline Value & Frequencies & Percentage \\
\hline Yes & 34 & $48.60 \%$ \\
\hline No & 27 & $38.60 \%$ \\
\hline I don't know & 9 & $12.90 \%$ \\
\hline Total & 70 & $100.00 \%$ \\
\hline
\end{tabular}

Table 19: Illustrates the knowledge nurses about management of sickle cell disease.

(Table 19) illustrate that the most of nurse's they are known about the curability of the SCD.

\begin{tabular}{|c|c|c|}
\hline Value & Frequencies & Percentage \\
\hline Yes & 59 & $84.30 \%$ \\
\hline No & 4 & $5.70 \%$ \\
\hline I don't know & 7 & $10.00 \%$ \\
\hline Total & 70 & $100.00 \%$ \\
\hline
\end{tabular}

Table 20: Illustrates Nurses knowledge regarding Treatment of sickle cell.

(Table 20) the illustrate views the most of nurses know about the treatment of SCD.

\begin{tabular}{|c|c|c|}
\hline Value & Frequencies & Percentage \\
\hline Yes & 56 & $80.00 \%$ \\
\hline No & 11 & $15.70 \%$ \\
\hline I don't know & 3 & $4.30 \%$ \\
\hline Total & 70 & $100.00 \%$ \\
\hline
\end{tabular}

Table 21: Illustrates the knowledge of nurses about affects ness the severity of sickle cell disease.

(Table 21) the illustrate views the most of nurses know about the affects ness of the disease (environmental and socioeconomic status).

\begin{tabular}{|c|c|c|}
\hline Value & Frequencies & Percentage \\
\hline Yes & 67 & $95.70 \%$ \\
\hline No & 2 & $2.90 \%$ \\
\hline I don't know & 1 & $1.40 \%$ \\
\hline Total & 70 & $100.00 \%$ \\
\hline
\end{tabular}

Table 22: Illustrates the knowledge of nurses about counseling sicklier patient.

(Table 22) the illustrate views the most of nurses know about the health education and counseling is play rolling in management of SCD. 


\section{Nursing \& Healthcare International Journal}

\begin{tabular}{|c|c|c|}
\hline Value & Frequencies & Percentage \\
\hline Yes & 18 & $25.70 \%$ \\
\hline No & 26 & $37.10 \%$ \\
\hline I don't know & 26 & $37.10 \%$ \\
\hline Total & 70 & $100.00 \%$ \\
\hline
\end{tabular}

Table 23: Illustrates the knowledge of the nurses about given for health education of sickle cell disease.

(Table 23) show that most of nurses didn't give and persuade the health education for the children and their family.

\begin{tabular}{|c|c|c|}
\hline Value & Level of education & $\begin{array}{c}\text { Years of } \\
\text { experiences }\end{array}$ \\
\hline Correlation & 0.67 & 0.96 \\
\hline Sig. (2-tailed) & 0.028 & 0.03 \\
\hline $\mathrm{N}$ & 70 & 70 \\
\hline
\end{tabular}

Table 24: Correlation between nurses knowledge about sickle cell disease their Level of education and their experiences.

There is a statistically significant relationship between level of education and knowledge about sickle cell disease was (0.67) with P-value $(0.028)$ which is lower than the level of the significant value (5\%) These refer to the existence relationship.

There is a statistically significant relationship between years of experience and knowledge about sickle cell disease was $(0.96)$ with P-value $(0,000)$ which is lower than the level of the significant value (5\%) these refer to the existence relationship.

\section{Discussion}

This study conducted in Ribat university hospital to assessment the level of knowledge for nursing staff of pediatric patients with 'SCD'. In general the results indicate that staff nurses in pediatric department they are a knowledgeable about SCD.

The Study revealed demographic data that majority of nurses $(61.4 \%)$ ranged in age (20-30) and show that majority of nurses are female $(98.6 \%)$. in this study the level of education was found to be factor that influenced that level of knowledge as the findings reveal differences between nurses holding associated diploma, bachelor, and post graduate, this finding explain the majority of nurses holding bachelor (84\%). The study also showed that half of nurses working experience (1-5 years) (55.7\%) and $34.3 \%$ of nurses working experience (6-10 years).
This study found that $(94.3 \%)$ of nurses knowledgeable regarding definition of SCD (Table 5) this finding similar to study of (Marie Osline Etine 1998) reported (97.8\%) that availability of SCD is genetic disorder [12].

The study showed the result of ethnic group in world African (90\%) of nurses knowledgeable (Table 6) this study similar with (Marie Osline Etiene 1998) were reported the black people is common ethnic group effect (49.9\%) [12].

The study showed the result of ethnic group in Sudan effect with SCD common in western Sudan $(87,1 \%)$ of nurses knowledgeable (Table 7) this finding is similar of previous study by (Bakheita Atalla 2003) were (70\%) reported in western Sudan [11].

The study revealed that (75\%) of nurses they are not know the health education and to estimated life expectancy (Table 8) the finding disagree with previous study by Orah S Platt, MD, journal 1994 [13]. The study result revealed that $(87.1 \%)$ of nurses they are knowledgeable about clinical manifestation of SCD (Table 9) this finding looks like previous study by Marie Osline Etiene 1998 [12].

The study result revealed that $(90 \%)$ of nurses they are knowledgeable about pain episodes (Table 10) this finding agree with previous study by (Nagwa Sayed 1997) $(81,2 \%)$ were reported in painful episodes cause hospital admission in children [14].

The study showed the result of antenatal screening is appropriate test $(74.3 \%)$ of nurses they are knowledgeable [7], this findings looks like previous study by (Nagwa Sayed 1997) where the reported the antenatal screening is one of investigation of SCD [14].

The study show (88.6\%) of nurses are knowledgeable about testing of SCD (Table 12) this finding agree with (Nagwa Sayed 1997) were reported (85.5\%) pallor are positive test of electrophoretic mobility of HPSS investigated her study group to confirm the diagnosis of SCD [14]. Also about the shape of RBCs of SCD (Table 13). This finding also agrees with (Nagwa Sayed 1997) [14].

The study show (95.7\%) agreed by nurses that general management of SCD are maintained adequate fluid intake, treat infection and vitamin supplementary (Table 14), this finding is similar of study (Nagwa Sayed 1997) were reported $100 \%$ of all patients receive folic acid I.V fluid 


\section{Nursing \& Healthcare International Journal}

and antibiotic regarding management of patients in her study group [14].

The study show $(81.4 \%)$ of nurses is knowledgeable regarding management of pain episodes (Table 15) and show that $(90 \%)$ of nurses knowledgeable regarding management of sever painful crises (Table 16), this finding disagree with (Shafeega Hassan 2015) were reported (47.8\%) of nurse's knowledge about pain assessment and management [15].

The study show $(80 \%)$ of nurses are knowledgeable about stroke management (Table 17) this finding agree with (Nagwa Sayed 2003) were reported $(8.7 \%)$ had past history of stroke received prophylactic transfusion, although the chronic transfusion program is more appropriate ways of management [14].

The study show (81.4\%) of nurses are knowledgeable about complication of SCD (pain crises), stroke and long tissue damage (Table 18), and also showed (85.7\%) of nurses knowledgeable about splenomegaly also complication of SCD (table 15) this finding indicate the nurses have good knowledge regarding complication of SDC, this finding is consistant with previous study conducted by (Mary Oslin 1998) regarding knowledge base invented item correct response score of nurses [12].

The study show (51.5\%) of nurses they are not know SCD is curable disease (Table 19) this result indicate the nurses have low knowledge this finding agree with (Nagwa Sayed 2003) recommended in her search to deliver proper medical services and provide center needed with concentration on the effects of genetic factor and beta globin haplotypes in Sudan [14].

The study show (84.3\%) of nurses are knowledgeable regarding SCD mange by bone marrow transplantation and gene therapy (Table 20) this result agree with (Nagwa Sayeed 1997) express in management of SCD [14]. The study show $(80 \%)$ of nurses are knowledgeable about environmental and socioeconomic status affect severity of disease (Table 21) this finding agree with (Nagwa Sayeed 1997) were reported $(60.9 \%)$ is poor socioeconomic status this finding poorer socioeconomic class tent to manifest more clinical courses [14].

The study show $(95.7 \%)$ of nurses agree the education and counseling play a role in management (Table 23) this finding agree with (Marsh J Treadwell 2006) were reported focus group members directly affected by SCD under scored need for counseling about SCT that is perceived as trust worthy. Peer educator and advance practice nurse how have experience with high risk, underserved clients may be effective in delivering information that is easily understood by individuals within the community $[16,17]$.

\section{Conclusion}

Based on the findings of the present study it was conducted that most of nurses in this study were knowledgeable about definition, clinical manifestation, management and complication. And they are not knowing the health education of sickle cell disease (75\%) and also (50\%) they are not knowing if sickle cell disease is curable or not.

\section{Recommendation}

\section{Nurses}

- More refreshment courses need to the nursing staff so that they obtain new trained and orientation programs would be continually to educate new staff nurses about SCD. Patients with SCD are dependent on nurses and health professionals for education, counseling and pain.

- Steps of universal precaution and crises management must be applied in pediatric emergency word to received child's life and reduce pain.

\section{Hospital}

- Nursing staff must be contributing in every international programmed and participate in conferences and workshops to be updated.

- Continuing nursing education is imperative in order for nurses to be equipped to face the challenges of the future in dealing with health care issues as they relate to patient care.

\section{References}

1. Wetherall DJ (1996) Disorders of the synthesis or function of haemoglobin. In: Wetherall DJ, et al. (Eds.), Oxford Textbook of Medicine, $3^{\text {rd }}$ (Edn.), Oxford University press, pp: 3500-3520.

2. Preutz MF (1976) Structure and mechanism of Hemoglobin. Br Med Bull 32(2): 195-208.

3. Nagel RL, Erlingsson S, Farby ME, Croizat H, Susuka SM, et al. (1991) The Senegal DNA haplotype is associated with the amelioration of anaemia in Africa 


\section{Nursing \& Healthcare International Journal}

American sickle cell anaemia patients. Blood 77(6): 1371-1375.

4. Sergeant GR (1994) The geography of sickle cell disease: opportunity for understanding its diversity. Ann Saudi Med 14(3): 237-246.

5. Sergeant GR (1997) Sickle cell disease. Lancet 350(9079): 725-730.

6. Preutz MF (1976) Structure and mechanism of hemoglobin. Br Med Bull 32(3): 195-208.

7. Sergeant GR. Sergeant BE, Manson K (1997) Heterocellular hereditary persistence of fetal hemoglobin and homozygous sickle cell disease. Lancent 1(8015): 795-796.

8. Honig GR (2000) Hemoglobin disorders. In: Behrman RE, et al. (Eds.), Nelson Textbook of Pediatrics. $16^{\text {th }}$ (Edn.), Philadelphia: WB Sounders, pp: 1478-1488.

9. Pauling L, Itano HA, Singer SJ, Wells IC (1949) Sickle cell anemia, molecular disease. Science 110(2865): 543-548.

10. Nagel RL, Fabry ME, Pagnier J, Zohun I, Wajcman H, et al. (1985) Hematologically and genetically distinct forms of sickle cell anemia in Africa, the Senegal type and the Benin type. N Eng J Med 312(14): 880-884.
11. Adam BA (2003) Sickle cell trait in sudaneses population in sudan, Bahar Algazal University.

12. Etine MO (1998) Knowledge and attitudes regarding patients with sickle cell disease among nurses in USA.

13. Platt OS, Brambilla DJ, Rosse WF, Milner PF, Castro O, et al. (1994) Morality in sickle cell disease, life expectancy and risk factor for early death. N Engl J Med 330(23): 1639-1644.

14. Nagwa Sayed Elhassan (1997) Clinical indicators of severity of sickle cell disease in children thesis submitted for the partial fulfillment for the degree of clinical MD in pediatrics and child health. Omdurman Islamic university.

15. Shafeega Hassan Yagoob (2015) Nurses' knowledge and attitudes toward pain assessment and management for adult sickle cell disease patients during sickling crisis. Clinical Nursing Studies 3(4): 36-43.

16. Treadwell MJ, McClough L, Vichinsky E (2006) Using qualitative and quantities strategies to evaluate knowledge and perceptions about sickle cell disease and sickle cell trait. J Natl Med Assoc 98(5): 704-710.

17. Perrine RP, John P, Pembery M, Perrine S (1981) Sickle cell disease in Saudi Arabs in early childhood. Arch Dis Child 56(3): 187-192. 